\title{
Leadership Behaviours and Academic Performance in Iraqi Public Universities: A Review
}

\author{
Hakim Hsoonee Almayali, Zainal Ariffin Bin Ahmad* \\ College of Graduate Studies University Tenaga Nasional, Kajang Selangor, Malaysia \\ *azainal@uniten.edu.my
}

\begin{abstract}
In line with the "National Strategy 2009-2013" launched by the Iraqi Ministry of Higher Education and Scientific Research (MOHESR), this study proposed to investigates the behaviour of university leaders (transformational leadership or transactional leadership behaviour) in enhancing academic performance of Iraqi public universities (including teaching, research, service, and staff satisfaction). A review of the literature suggests that there is positive relationship between leadership behaviour and academic performance in higher education; however, there is a dearth of studies investigating this relationship. The results are expected to show that leadership behaviour has positive relationship on academic performance in Iraqi HEIs. (98 words)
\end{abstract}

Keywords: Leadership behavior, academic performance, public universities, academic leaders

\section{Introduction}

There is a large body of literature pertaining to leadership and job performance of middle managers in business; however, similar studies of leadership behaviour and academic performance in (HEIs) are lacking especially in the Arab countries. The context of this study is Iraq, a developing country in the redeveloping stage. Iraq is situated in the Middle South- west of the Asia with a population of 30 million people. As reported in the Report of Iraqi Ministry of Higher Education and Scientific Research (2011), Iraq institutionalized the first college of law in 1908, which was subsequently followed by an increased number of colleges and academies between the 1920s and 1950s in various Iraqi cities. The first university was, the University of Baghdad in 1957, the University of Al-Mustansiriyah, was institutionalized in 1963, the University of Basrah in 1964 and the University of Mosul in 1967. Therefore, HEIs have considered teaching, research, and service of society as part of their mission. In 1975, the Iraqi government and leaders of HEIs rendered adequate aid in this sector by supporting various facilities, such as teaching, research, service, curriculum, laboratories, scholarship, and training in order to develop knowledge among society. Therefore, Iraq had one of the soundest educational systems in the 1970-1980s among the Arab world universities (Janabi \& Urban, 2011). Iraqi 1991 to 2003, following Iraq's occupation of Kuwait in 1991, the United Nations Security Council (UNSC) enacted economic sanctions that kept Iraq away from the rest of the world. This led to the mass destruction of information technology and reduced support for academic staff to enhancing teaching method, research, and service in Iraqi HEIs. As a result of the wars, Iraqi HEIs suffered the destruction of many of its universities, as well as arson and looting, such as in the University of Basrah and Mustansiriyah (Report the Minister of Higher Education, 2012). Further, Iraq's lack of security forced hundreds of scientific intellectuals from various specializations to leave their universities. Iraq has been facing significant deterioration in HEIs because of weak international contact (Janabi \& Urban, 2011). Therefore, the situation in which Iraqi HEIs has been deteriorating since 1991 and has led to a decline in education levels of Iraqi HEIs (Janabi \& Urban, 2011; UNESCO, 2003). This has destroyed education in Iraq, and Iraqi universities have not appeared among the top universities of the world since 1991.

Darwish and Yousef (2000) and Swanson and Johnson (1975) mentioned that leadership behavior influences performance. In the higher education setting, Niles (1997) and Nordin (2011) argue that leadership behavior in HEIs can be viewed as transformational and transactional leadership behavior. Although researchers differ somewhat in their definitions of transformational leadership and its associated behaviors, it has been found that transformational leadership behaviors induce positive employee behaviors and organizational outcomes (Emery \& Barker, 2007; Stashevsky \& Koslowsky, 2006). Both transactional and transformational leadership behaviors show positive relationships with enhancing performance (Dubinsky, Yammarino, Jolson, \& Spangler, 1995; Nordin, 2011). Transformational leadership behavior provides motivation and influence performance of followers (Bono \& Judge, 2004). In addition, transactional leadership behavior makes use of contingent reward, and leaders display positive strengths to execute goals (Eid, Johnsen, Bartone, \& Nissestad, 2008). In this study, the researcher investigates leadership behavior by examining the behavior of the university leaders and associates them with a particular behavior; namely transformational leadership or 
transactional leadership behavior in university setting (Niles, 1997; Nordin, 2011). These leadership behaviors provide motivation and support to enable the staff to develop their achievement (Nguyen \& Mohamed, 2011). The achievements of performance in most organizations depend on leadership. There is a need for more adaptive, flexible leadership in today's rapidly changing organizational landscape (Bass, Avolio, Jung \& Berson, 2003). It is important to find, develop, and keep effective leaders for organizational success (Fairholm \& Fairholm, 2000; Zehner \& Holton, 2004). According to Kouzes (1999), when followers work with leaders who care for them and encourage them, the followers feels better about them and perform at significantly higher levels. These leadership behaviors are characteristics of the transformational leadership behavior and transactional leadership behavior. In the context of HEIs, there seems to be a lack of empirical studies that link leadership behavior of the university leaders to achieve performance (Niles, 1997; Nordin, 2011).

\section{Literature Review}

Academic Performance: Academic performance is defined as a quantity that measures some elements of an institution or its activity (Gaither, Nedwek, \& Neal, 1994). Academic performance is measured using Academic Performance Indicator (API). Due to the pressing needs of accountability and assessment, there is a demand in the use API which is defined as "a concrete piece of information about the condition or result of public action that is regularly produced, publicly reported, and systematically used for planning, monitoring, or resource allocation at the state or system level such indicators are intended to be used together, not singly or out of context" (Ewell, 1994). Further, API has been fundamentally defined as a quantitative measure related to an event or activity (Sapp, 1993). Academic performance indicators have become tools for guiding governance and improvement of HEIs (Dooris \& Teeter, 1994). Thus, in the context of HEIs, the measure of performance in public universities must take into account academic performance indicators (API) including teaching, research, service, and academic satisfaction (Agha, 2007; Hashim, 2009; Zwain et al., 2012). However, little empirical research has been conducted to investigate academic performance in Iraqi HEIs (Iraq-HEOC, 2007; Zwain et al., 2012). Therefore, in present study, academic performance is operationalized as quantitative measure linked to academic activities of teaching, research, service, and satisfaction of academic staff (Tang \& Chamberlain, 1997; Boyer, 1990; Hashim, 2009; Johnes, 1996; Mert1er, 2001). Hence, the Ministry of Higher Education and Scientific Research Iraq recently launched the "National Strategy 2009-2013" (Janabi \& Urban, 2011, p. 97). The strategic plan 2009-2013 covers the following aspects with precise objectives and a proper implementation schedule:

- Providing support for higher education in various ways to develop university leaders.

- Providing support for the MOHESR strategic plan together with other fields of higher

- Education in Iraq.

- Enhancement of faculty and staff.

- Develop Information Technology current and future.

- Study scholarships.

- Revising the curricula.

- Encourage and increase research productivity.

- Dissemination of research results.

- Minimizing brain drain through providing a basis for encouraging faculty, staff, and

- Students to remain loyal to the country.

- International contact.

- Develop teaching method.

- Develop curriculum $10-20 \%$ per year.

- Develop knowledge creation, dissemination, and application of knowledge.

- Procedure justice.

Leadership Behaviour: For the purpose of the current study, leadership behaviour is defined as an interaction between two or more members of a group which often involves a structuring or restructuring of the situation and the perceptions and expectations of the members. Thus, leadership occurs when one group member modifies the motivation and competencies of others in the group (Bass, 1990). According to Bass and Avolio (1994) and Bass (1985), transformational leadership is described by five factors;

- Idealized influence Behavior leaders behave in ways in which their actions are centred on values, beliefs, and a sense of mission. The leaders consider the needs of others over their own personal needs and share risks with followers.

- Idealized Influence Attributes: Respect, trust, and faith. 
This study proposed that leadership behavior in HEIs setting can be deemed as transformational and transactional leadership behavior (Niles, 1997). Both transactional and transformational leadership behavior show a positive relationship in enhancing performance (Dubinsky et al., 1995; Emery \& Barker, 2007; Stashevsky \& Koslowsky, 2006; Nordin, 2011). Transformational leaders influence motivation and performance of employees (Bono \& Judge, 2004), thus increases performance (Geyer \& Steyrer, 1998) among employees. In addition, transactional leadership behavior makes use of contingent reward, and leaders display positive strengthening to execute goal (Eid et al., 2008). Leadership in Iraqi HEIs is crucial in achieving excellence in academic performance (Taher \& Amian, 2007). Whereas, there is a large body of existing knowledge pertaining to leadership and job performance of middle managers in business, while similar studies of leadership behavior and academic performance in higher education institutions (HEIs) are lacking especially in the context of this study (Taher \& Amian, 2007). Therefore, the following hypotheses are postulated:

H1: There is positive relationship between leadership behavior and academic performance in Iraqi HEIs. H1a: There is positive relationship between transformational leadership behavior and academic performance in Iraqi HEIs.

H1b: There is positive relationship between transactional leadership behavior and academic performance in Iraqi HEIs.

\section{Expected Results}

The findings of the present study will contribute to the body of literature in leadership and higher education. It is expected that there will be positive relationship between leadership behavior and academic performance in the Iraqi public universities. The findings of this study may also address the gaps identified in literature. From the practical standpoint, the expected results of this study suggests that the evaluation of academic performance among academic staff will provide some information for the academic leaders of Iraqi HEIs as well as the Ministry of Higher Education and Scientific Research in support of the objectives of the National Strategy 2009-2013.

\section{Conclusion}

This proposed study investigates the behavior of university leaders in enhancing academic performance of Iraqi public universities. A review of the literature suggests that there is positive relationship between leadership behaviour and academic performance in higher education.

\section{References}

Agha, K. (2007). Key performance indicators: A successful tool for performance management in the education industry in the Sultanate of Oman. India Management Journal, 1(3/4).

Bass, B. (1999). Two decades of research and development in transformational leadership. European Journal of Work and Organizational Psychology, 8(1), 9-32.

Bass, B. M. \& Avolio, B. J. (1994). Improving organizational effectiveness through transformational leadership. Thousand Oaks, CA: Sage.

Bass, B. M. \& Avolio, B. J. (1997). Full range leadership development: Manual for the Multifactor Leadership Questionnaire. Palo Alto, CA: Mindgarden.

Bass, B. M. (1985). Leadership and performance beyond expectations. New York: Free Press.

Bass, B. M. (1990). Bass \& Stogdill's handbook of leadership: Theory, research and managerial applications (3rd Ed). London: Collier Macmillan Publisher.

Bass, B. M., Avolio, B. J., Jung, D. I. \& Berson, Y. (2003). Predicting unit performance by assessing transformational and transactional leadership. Journal of Applied Psychology, 88(2), pp. 207-218.

Bono, J. E. \& Judge, T. A. (2004). Self-concordance at work: toward understanding the motivational effects of transformational leadership. Academy of Management Journal, 46, 554-571.

Darwish, A. \& Yousef, H. (2000). Organizational commitment: a mediator of the relationships of leadership behavior with job satisfaction and performance in a non-western country". Journal of Managerial Psychology, 15(1), 6 - 24.

Deluga, R. J. (1990). The effects of transformational, transactional, and laissez faire leadership characteristics on subordinate influencing behavior. Basic and Applied. Social Psychology, 11, 191203.

Dooris, M. I. \& Teeter, D. 1. (1994). Total quality management perspective on assessing institutional 
performance. New Directions for Institutional Research, 16(2), 51-62.

Dubinsky, A. J., Yammarino, F. J., Jolson, M. A. \& Spangler, W. D. (1995). Transformational Leadership: An Initial Investigation in Sales Management. Journal of Personal Selling and Sales Management, 15, 2,17-31.

Eid, J., Johnsen, B. H., Bartone, P. T. \& Nissestad, O. A. (2008). Growing transformational leaders: exploring the role of personality hardiness. Leadership \& Organization Development Journal, 29(1), 4-23.

Emery, C. R. \& Barker, K. J. (2007). The effect of transactional and transformational leadership behaviors on the organizational commitment and job satisfaction on customer contact personnel. Journal of Organizational Culture, Communication and Conflict, 11, 77-90.

Ewell, P. T. (1994). In Ruppert, S. (Ed.), Charting higher education accountability: A sourcebook on statelevel performance indicators. Denver, CO: Education Commission of the States. (ERIC Document Reproduction Services No. ED 375789).

Fairholm, R. M. \& Fairholm, G. (2000). Leadership amid the constraints of trust. The Leadership \& Organizational Development Journal, 21(2), 102-109.

Gaither, G., Nedwek, B. P. \& Neal, 1. E. (1994). Measuring up: The promises and pitfalls of performance indicators in higher education (ASHE-ERIC Higher Education Report, No.5). Washington, DC: George Washington University.

Geyer, A. L. J. \& Steyrer, J. M. (1998). Transformational leadership and objective performance in banks. Applied Psychology: An International Review, 47, 397420.

Hashim, R. A. (2009). Perceived Leadership Behaviors and Commitment To Service Quality Among Academic Staff: The Mediating Influence Of Job Satisfaction. Thesis Ph.D. College of Business. Universiti Utara Malaysia.

Hautala, T. (2005). The effects of subordinates' personality on appraisals of transformational leadership. Journal of Leadership \& Organizational Studies, 11(4), 84-93.

Iraq-HEOC. (2007). International Conference on Higher Education in Iraq. Erbil: Final Report of Iraq Higher Education Organizing Committee (Iraq-HEOC), London, UK.

Janabi, S. A. \& Urban, J. E. (2011). Strategic plan for enhancing higher education computing degree programs in Iraq. Proceeding Global Engineering Education Conference (EDUCON). Amman, Jordan, April 4-6.

Kouzes, P. J. M. (1999). Getting to the heart of leadership. The Journal for Quality and Participation, 22(5), 64.

Nguyen, H. N. \& Mohamed, S. (2011). Leadership behaviors, organizational culture and knowledge management practices: An empirical investigation. Journal of Management Development, 30(2), 206-221.

Niles, G. P. (1997). A comparative study of leadership behaviors in university settings. PhD Thesis. University of Rochester.

Nordin, N. (2011). The influence of emotional intelligence, leadership behavior and organizational commitment on organizational readiness for change in higher learning institution. International Conference on Education and Educational Psychology (ICEEPS). Procedia - Social and Behavioral Sciences, 29, $129-138$.

Sapp, M. (1993). Setting up a key success indices report: A how-to manual. Paper Presented at the 33rd Annual Forum of the Association for Institutional Research, Chicago, IL. (ERIC Document Reproduction Services No. ED 360 909).

Stashevsky, S. \& Koslowsky, M. (2006). Leadership team cohesiveness and team performance. International Journal of Manpower, 27(1), 63 - 74.

Swanson, R. G. \& Johnson, D. A. (1975). Relation between peer perception of leader behavior and instructor pilot performance. Journal of Applied Psychology, 60, 198-200.

Taher, M. \& Amian, N. M. (2007). The Realties and Prospects of Higher Education in Kurdistan Region in the Eyes of the Teaching Staff. Proceeding in International Conference on Higher Education, Erbil. Iraq.

Zehner, R. L. \& Holton, E. F. (2004). Development and validation of an instrument for early assessment of management potential in a mid-size chemical company. Performance Improvement Quarterly, $17(3), 5-23$.

Zwain, A. A., Teong, L. K. \& Alimarah, A. T. (2012). The Impact of TQM Core Elements on Academic Performance: An Empirical Study of Iraqi Higher Education Institutions. Proceeding, Third Quality Research Conference. University of Kufa, 68-81. 